\title{
MIDDLE EAST TECHNICAL UNIVERSITY (METU) RADIOCARBON DATES I
}

\author{
MUSTAFA ÖZBAKAN \\ Radiocarbon Dating Laboratory, METU Physics Department \\ 06531 Ankara, Turkey
}

The Radiocarbon Dating Laboratory was established at the Middle East Technical University in the Physics Department with the equipment provided by the British Government through former CENTO auspices and financial support by the Ford Foundation. This list reports on ${ }^{14} \mathrm{C}$ dates measured up to July 1987.

The laboratory is built in the basement of a three-story building and uses $\mathrm{CO}_{2}$ gas for proportional counting. The system is equipped with three high-purity copper proportional counters (Twentieth Century Electronics). Each counter has an active volume of ca $2 \mathrm{~L}$.

The proportional counters are protected against cosmic ray and surrounding ionizing radiation by a passive $10 \mathrm{~cm}$-thick shield made of old lead (James Girdler \& Co, Ltd) and an active cylindrical plastic scintillator anticoincidence ring (Nuclear Enterprise NE 102A). Each copper proportional counter is separately placed inside a horizontal cylindrical cavity in the plastic scintillator which is viewed from both ends by two $30 \mathrm{~cm}$ photomultipliers (EMI 945B) to detect any external radiation passing through the system. In between the passive and active shields there is a neutron moderator in the form of small pellets made of $70 \%$ paraffin wax, $20 \%$ boric acid, and $10 \%$ polythene. The signals from both photomultipliers are first fed into individual preamplifiers and then added in a mixing unit before going to the amplifier. Output signals from the proportional counters are fed into separate signal processing channels through charge-sensitive preamplifiers built into the counters. Anticoincident ${ }^{14} \mathrm{C}$ signals from the counter are also fed into a 256-channel pulse height analyzer (Tracor Northern NS633) to obtain beta spectrum of each sample counted.

Only one of the counters is used for dating purposes. The usual operating pressure of the counter is $120 \mathrm{cmHg}$. Two other pressures, $100 \mathrm{cmHg}$, and $80 \mathrm{cmHg}$, are also used for smaller-sized samples. Counter plateaus are ca $700 \mathrm{~V}$ long with slopes $<1 \% / 100 \mathrm{~V}$ for cosmic rays at the operating pressure of $120 \mathrm{cmHg}$. The operating voltage at this pressure is ca $4750 \mathrm{~V}$. Modern standard $\mathrm{CO}_{2}$ is prepared by wet oxidation of NBS oxalic acid and background $\mathrm{CO}_{2}$ is prepared by combustion of anthracite. At the operating pressure of $120 \mathrm{cmHg}$, the background is $9.74 \pm 0.06 \mathrm{cpm}$ and net modern (95\% of NBS oxalic acid) corresponding to AD $1950{ }^{14} \mathrm{C}$ count rate is 15.92 $\pm 0.10 \mathrm{cpm}$. Every sample is counted for $>48$ hours with 200 minute repeating periods. The background and the NBS oxalic acid standard are counted at least twice a month.

Samples are examined for contamination and a physical cleaning is followed by a standard acid-alkali-acid treatment. After each treatment the sample is rinsed with distilled water until neutralization is achieved, and is made slightly acidic before it is dried overnight at $100^{\circ} \mathrm{C}$. Charcoal, wood, 
charred grains, and anthracite for background are converted to $\mathrm{CO}_{2}$ by controlled combustion in a quartz tube with a stream of commercial oxygen gas coming through washed bottles containing $1 \% \mathrm{NaOH}$ solution. The combustion products of the sample are initially purified by passing over several $\mathrm{KMnO}_{4}$ solutions and water traps cooled at $-78^{\circ} \mathrm{C}$. The $\mathrm{CO}_{2}$ is collected with liquid nitrogen and further purification is achieved by circulating the $\mathrm{CO}_{2}$ over $450^{\circ} \mathrm{C}$ hot $\mathrm{CuO}$. The purified $\mathrm{CO}_{2}$ is stored for about four weeks to ensure radon decay. Prior to each counter filling, the $\mathrm{CuO}$ furnace is reduced to $\mathrm{Cu}$ by passing hydrogen gas at $450^{\circ} \mathrm{C}$ and the $\mathrm{CO}_{2}$ is routinely circulated several times over $450^{\circ} \mathrm{C}$ hot $\mathrm{Cu}$ and is vacuum distilled at $-78^{\circ} \mathrm{C}$. After this procedure, $\mathrm{CO}_{2}$ quality is satisfactory for proportional counting and, therefore, the $\mathrm{CaO}$ purification furnace present in the system is not used.

Dates are expressed in years BP (AD 1950) using the half-life for ${ }^{14} \mathrm{C}$ of 5568 years (Stuiver \& Polach, 1977). Errors quoted with dates are based only on counting statistics and correspond to $\pm 1 \sigma$ of sample, background, and modern standard. No $\delta^{13} \mathrm{C}$ values were measured and dates have not been corrected for isotopic fractionation. No corrections were made for natural ${ }^{14} \mathrm{C}$ variations.

\section{ACKNOWLEDGMENTS}

The author would like to express his deep gratitude to Hakki Ögelman who made it possible to operate the laboratory and $\mathrm{H}$ Yeter Göksu for her valuable advice and guidance. I am grateful to Mebus A Geyh of the Hannover Radiocarbon Laboratory with whom I had the privilege to work for six months and study the experimental method. I am also grateful to the British Government and to the Ford Foundation for their equipment and financial support. M J Baker is responsible for the design and construction of the system.

\section{ARCHAEOLOGIC SAMPLES}

Turkey

\section{Phrygian series}

Wooden beam from Gordion $\left(39^{\circ} 45^{\prime} \mathrm{N}, 31^{\circ} 55^{\prime} \mathrm{E}\right)$, ca $110 \mathrm{~km} \mathrm{SW}$ of Ankara, in very good state of preservation. Beam was taken from tomb in Great Tumulus. $\mathrm{NaOH}$ pretreatment. Comment: series of dates for same site was pub previously (P-127, $-128,-133$ to -137 : $\mathrm{R}, 1959$, v 1, p 45-58). Another wooden sample from Great Tumulus, Phrygian site, Bahçelievler, Ankara. It contains too much humic acid. $\mathrm{NaOH}$ and $\mathrm{HCl}$ treatment.

METU-3. Gordion

$2650 \pm 200$

METU-4. Bahçelievler

$2550 \pm 200$

\section{Ikiztepe series}

Charcoal and charred grains from Ikiztepe Mound, ca $7 \mathrm{~km} \mathrm{NW}$ of Bafra, Samsun at Black Sea Coast. There are four distinct tumuli at site; 
only Tumulus I and Tumulus II were excavated. Three main periods, Chalcolithic, Early Bronze Age, and Early Hittite (or Transition), were assigned to site on archaeol grounds. Six phases of Early Hittite period are present in Tumulus I, at $6 \mathrm{~m}$ depth from surface. Upper levels of Tumulus II were eroded and seven phases of Early Bronze Age occur at $5 \mathrm{~m}$ depth. Seven phases of Chalcolithic period occur at $5.5 \mathrm{~m}$ depth. All samples coll and subm by late $\mathrm{U}$ Bahadir Alkim, Istanbul Univ. $\mathrm{NaOH}$ and $\mathrm{HCl}$ pretreatment.

METU-5. Ikiztepe 6

$5170 \pm 170$

Tumulus II, charcoal mixed with soil, Loc b 517, D-13/II-19.

METU-6. Ikiztepe 8

$3690 \pm 160$

Tumulus I, charred grains mixed with soil, Loc b 421, D-4/IV-11.

METU-7. Ikiztepe 15

$4270 \pm 100$

Tumulus I, charred grains mixed with soil, Loc b 422, D-4/IV-12.

METU-8. Ikiztepe 18

$5550 \pm 120$

Tumulus II, charcoal mixed with soil, Loc b 116, D-11/II-19.

\section{METU-9. Ikiztepe 22}

$4030 \pm 100$ D-13/II-1.

\section{Çayönü series}

Charcoal from Çayönü Tumulus (38 $\left.16^{\prime} \mathrm{N}, 39^{\circ} 43^{\prime} \mathrm{E}\right)$, Diyarbakir in Turkey (Braidwood, Çambel \& Shirmer, 1981; Cambel, 1981, p 151). Samples are mixed with soil. $\mathrm{NaOH}$ and $\mathrm{HCl}$ pretreatment. Samples coll and subm by Halet Cambel, Istanbul Univ. Comment: series of 20 dates for same site was pub previously (GrN-4458, -4459: R, 1967, v 9, p 107-155; GrN$5827,-5952$ to $-5954,-6241$ to $-6244,-8078,-8079,-8103,-8819$ to -8821 , -10358 to -10361 : Crambel, 1984, p 20). GrN-8079, 9250 BP or GrN-8821, 9175 BP date beginning of site.

\section{METU-10. Çayönü 2}

$9510 \pm 100$

Charcoal mixed with soil. Excavation R-3/4-0.51.

METU-11. Çayönü 3

$10,480 \pm 220$

Charcoal mixed with soil. Excavation R-5/11/1.10.

METU-12. Çayönü 4

$10,820 \pm 220$

Charcoal mixed with soil. Excavation R-5/13-7.08 Tr-1.13.

METU-13. Çayönü 5

$5940 \pm 150$

Charcoal mixed with soil. Excavation R-4/10-0.74 Tr-0.82. 


\section{Keban series}

Charcoal and charred grains coll from Tepecik Tumulus $\left(38^{\circ} 39^{\prime} \mathrm{N}\right.$, $\left.39^{\circ} 26^{\prime} \mathrm{E}\right)$ and Tülintepe Tumulus ( $\left.38^{\circ} 38^{\prime} \mathrm{N}, 39^{\circ} 24^{\prime} \mathrm{E}\right)$ Altinova, Elaziğ, ca $30 \mathrm{~km}$ E of Elaziğ. Both tumuli are now flooded as result of Keban Dam built in region. Tepecik Tumulus was assigned on archaeol grounds to beginning of Late Neolithic. Early and Late Chalcolithic, Early, Middle, and Late Bronze Ages, Iron Age, and Middle Ages cultural levels are present in Tepecik. Upper levels of Tülintepe Tumulus were destroyed and only Early and Late Chalcolithic cultural levels were excavated (Esin, 1982, p 95; Esin \& Arsebük, 1982, p 127). All samples coll and subm by Ufuk Esin, Istanbul Univ.

METU-14. Tepecik (K-15B)

$4000 \pm 60$

Charcoal, Loc K, 74, 12K, 4.

METU-15. Tepecik (K-19)

$4790 \pm 60$

Charcoal, Loc A, 16A, 3, BT2.

METU-16. Tepecik (K-22A)

$2890 \pm 60$

Charcoal mixed with soil, Loc K, 70, 7K, 4,29.

METU-17. Tülintepe (K-4)

$6160 \pm 150$

Charred grains, Loc I, 531, 1, B, 10.

METU-18. Tülintepe (K-6)

$5360 \pm 180$

Charred grains, Loc L, 54L, 18.

METU-19. Tülintepe (K-7)

$5730 \pm 190$

Charred grains, Loc I, 71, 481, 2,2.

REFERENCES

Alkim, U, 1984, Arkeometri Ünitesi Bilimsel Toplanti Bildirileri I: Ankara, Tübitak pub no. $591,233 \mathrm{p}$

Braidwood, R J, Cambel, H and Shirmer, W, 1981, Beginnings of village-farming communities in southeastern Turkey, Çayönü Tepesi, 1978 and 1979: Jour Field Archaeol, v 8, p 249258

Cambel, H, 1981, Arkeometri Ünitesi Bilimsel Toplanti Bildirileri II: Istanbul, Boğaziçi Univ Press, 182 p. 591,233 p.

Esin, U, 1982, Keban Proj 1974-1975 activities: Middle East Tech Univ Keban Proj pub ser I, no. 7, Turkish Hist Soc Press, 435 p.

Esin, U and Arsebük, G, 1982, Keban Proj 1974-1975 activities: Middle East Tech Univ Keban Proj pub ser I, no. 7, Turkish Hist Soc Press, 435 p.

Ralph, E K, 1959, University of Pennsylvania radiocarbon dates III: Am Jour Sci Radiocarbon Supp, $v 1$, p 45-58.

Stuiver, $\mathrm{M}$ and Polach, H A, 1977, Discussion: Reporting of ${ }^{14} \mathrm{C}$ data: Radiocarbon, $v 19$, no. 3, p 355-363.

Vogel, J C and Waterbolk, H T, 1967, Groningen radiocarbon dates VII: Radiocarbon, v 9, p $107-155$. 